\title{
Platinum stabilized by defective activated carbon with excellent oxygen reduction performance in alkaline media
}

\author{
Xuecheng Yan, Yi Jia *, Longzhou Zhang, Xiangdong Yao \\ School of Natural Sciences and Queensland Micro- and Nanotechnology Centre, Griffith University, Nathan Campus, QLD 4111, Australia
}

A R T I C L E I N F

\section{Article history:}

Received 17 November 2016

Accepted 31 December 2016

Published 5 June 2017

\section{Keywords:}

Activated carbon

Defect

Platinum

Oxygen reduction reaction

Fuel cell

\begin{abstract}
A B S T R A C T
The exploration of highly active and durable cathodic oxygen reduction reaction (ORR) catalysts with economical production cost is still the bottleneck to realize the large-scale commercialization of fuel cells and metal-air batteries. Given that carbon support is crucial to the electrocatalysts, and Pt is the best-known ORR catalyst so far, in this work, we employed a simple impregnation method for synthesizing a kind of defective activated carbon (D-AC) supported low Pt content electrocatalysts for the ORR. The reduction conditions of the Pt-containing precursor were firstly optimized, and the influence of the Pt loading amount on the ORR was investigated as well. The results show that the obtained D-AC@5.0\%Pt sample (contains 5 wt\% Pt) has surpassed the commercial Pt/C with $20 \mathrm{wt} \% \mathrm{Pt}$ for the ORR in an alkaline solution. In the meantime, it is more stable than the commercial Pt/C. The outstanding ORR performance of the D-AC@5.0\%Pt confirms that both the unique defects in the D-AC and the introduced Pt particles are indispensable to the ORR. Particularly, the ORR activity of the synthesized catalysts is superior to most of the reported counterparts, but with much easier preparation methods and lower production cost, making them more advantageous in practical fuel cell applications.
\end{abstract}

(C) 2017, Dalian Institute of Chemical Physics, Chinese Academy of Sciences. Published by Elsevier B.V. All rights reserved.

\section{Introduction}

Proton exchange membrane fuel cell is the most possible candidate to replace the current internal combustion engines in vehicles because of its high energy conversion efficiency and pollution-free characters. However, the sluggish cathodic oxygen reduction reaction (ORR) in fuel cells substantially reduces the overall cell performance, and the development of ORR catalysts with remarkable activity remains a big challenge [1]. Currently, platinum (Pt) and its alloys are still the main component of the ORR catalysts owing to their outstanding catalytic activity in both alkaline and acidic media [2-4], while the high cost of $\mathrm{Pt}$ and the stability issues greatly hinder its massive application [5,6]. To alleviate these shortcomings, considerable advances have been achieved on Pt alloys to reduce the utiliza- tion of Pt, such as Pt-Fe [7-9], Pt-Ni [4,10,11], and Pt-Co [12-14]. Besides, it was found that the core-shell structures are also favorable to increase the activity and durability of Pt-based ORR catalysts [15-18]. However, the preparation of these materials normally involves the use of hazardous organic chemicals with tedious synthesis process, which is not suitable for practical large-scale production. Therefore, it is highly desirable to develop a facile method to fabricate efficient ORR catalysts with economical manufacturing cost.

Previous investigations illustrate that the support for Pt is crucial to enhance the ORR performance of the resulting catalysts [19-21]. It can be found that most of the supports are modified carbon materials, including micro/mesoporous carbons [22,23], heteroatom doped graphene [24,25], and defective carbons $[21,26]$. These carbon materials with tuned micro- 
structures and modified electronic environment are favorable for the electrocatalytic reactions. Recently, the defective carbons are being paid more attention owing to a new defect catalysis mechanism was proposed, demonstrating that specific types of defects in carbon materials not only could serve as the active sites for electrocatalytic reactions but also could provide more efficient anchor sites to couple metal atoms [26-29]. With respect to the pure defective carbon catalysis, albeit the activity of the defective activated carbon (D-AC) is superior to most of the reported metal-free ORR catalysts, it is still inferior to the commercial $\mathrm{Pt} / \mathrm{C}(20 \mathrm{wt} \% \mathrm{Pt})$ [26]. In view of $\mathrm{Pt}$ is the best-known ORR catalyst so far, as aforementioned, if we can reduce the amount of $\mathrm{Pt}$ by using the $\mathrm{D}-\mathrm{AC}$ as a carbon support, but without sacrificing the activity, it should be a promising approach to tackle the high cost problem of the cathodic catalyst and realize the mass production of fuel cells.

In the present work, a simple impregnation method was employed to prepare effective ORR electrocatalysts by using the D-AC as a support for the Pt. The Pt particle size manipulation was achieved by controlled thermolysis process, and the influence of the Pt concentration on the ORR activity of the resulting catalysts was also discussed. The results show that the obtained D-AC@5.0\%Pt sample (only contains $5 \mathrm{wt} \% \mathrm{Pt}$ ) has outperformed the commercial Pt/C (20 wt\% Pt) in an alkaline solution, indicating that the defective carbon not only could serve as an efficient ORR catalyst alone, but also an appropriate carbon support for the Pt to promote the ORR.

\section{Experimental}

\subsection{Catalyst preparation}

The defective carbon D-AC was synthesized through a facile nitrogen-doping and removal method, as described elsewhere [26]. Specifically, the D-AC with a certain mass was dispersed into the designed $\mathrm{H}_{2} \mathrm{Cl}_{6} \mathrm{Pt} \cdot 6 \mathrm{H}_{2} \mathrm{O}$ /ethanol solution with $5 \mathrm{~min}$ sonication for better mixing. Afterwards, the mixture was placed on a stirrer to stir overnight to remove the ethanol at room temperature. The obtained precursor was reduced in the presence of a mixture gas of $5 \% \mathrm{H}_{2}-95 \% \mathrm{Ar}$ at the target temperatures in a tubular furnace. The gas was purged for $30 \mathrm{~min}$ to expel the air inside the tube before operating the reduction program.

\subsection{Characterizations}

The crystalline structures of the prepared samples were characterized by X-ray powder diffraction (XRD) in a Bruker Advance X-ray diffractometer using nickel-filtered $\mathrm{Cu} K \alpha \mathrm{X}$-ray source radiation $(\lambda=0.15405 \mathrm{~nm})$. The morphologies and structures of the materials were examined by using transmission electron microscopy (TEM) and high-resolution TEM (HRTEM) (Philips Tecnai F20). Chemical compositions of the prepared samples were acquired using a Kratos Axis ULTRA X-ray photoelectron spectrometer incorporating a $165 \mathrm{~mm}$ hemispherical electron energy analyzer. The incident radiation is Monochromatic Al $K_{\alpha} \mathrm{X}$-rays $(1486.6 \mathrm{eV})$ at $150 \mathrm{~W}(15 \mathrm{kV}, 10$
$\mathrm{mA}$ ). The energy scale was calibrated to the $\mathrm{C} 1 \mathrm{~s}$ peak maximum at $284.5 \mathrm{eV}$. The Pt contents of the prepared samples were determined by inductively coupled plasma mass spectroscopy (ICP-MS) on the Perkin Elmer Optima 8300 ICP-OES instrument.

\subsection{Electrochemical measurements}

The typical three-electrode system was employed to evaluate the electrochemical properties of the prepared catalysts. Specifically, glassy carbon (GC) was the working electrode, a Pt wire was the counter electrode and the $\mathrm{Ag} / \mathrm{AgCl}$ (in saturated $\mathrm{KCl}$ solution) was the reference electrode. All potentials were referred to the reversible hydrogen electrode by adding a value of $(0.197+0.059 \mathrm{pH}) \mathrm{V}$. Cyclic voltammetry (CV), linear sweep voltammetry (LSV) and rotating ring-disk electrode (RRDE) measurements were conducted on the $\mathrm{CHI} 760 \mathrm{E}$ workstation (CH Instruments, Inc.) with a RRDE-3A rotator ( $A L S$ Co., Ltd).

\subsubsection{Sample preparation}

$1 \mathrm{mg}$ of the catalyst was dispersed into $1 \mathrm{~mL}$ mixed solution of distilled water $(680 \mu \mathrm{L})$, ethanol $(300 \mu \mathrm{L})$ and Nafion ${ }^{\circledR} 117$ Solution $(5 \%, 20 \mu \mathrm{L})$. Then, $10 \mu \mathrm{L}$ of the mixture was dropped onto a polished glassy carbon electrode $(4 \mathrm{~mm}$ in diameter, catalyst loading: $0.08 \mathrm{mg} / \mathrm{cm}^{2}$ ) after sonicating it for at least 60 min to form a homogeneous ink. The loaded electrode was placed in a $60{ }^{\circ} \mathrm{C}$ oven for $10 \mathrm{~min}$ and then was taken out to cool down before all the tests.

\subsubsection{CV measurement}

Prior to the test, the electrolyte $(\mathrm{KOH}$ solution $(0.1 \mathrm{~mol} / \mathrm{L}))$ was bubbled with $\mathrm{O}_{2}$ for at least $30 \mathrm{~min}$ to make it saturated with $\mathrm{O}_{2}$, and a constant oxygen flow was maintained during the measurement. The data was recorded at the scan rate of 100 $\mathrm{mV} / \mathrm{s}$ when the system became stable.

\subsubsection{LSV measurement}

The rotating speed of the working electrode was increased from 400 to $2500 \mathrm{r} / \mathrm{min}$ at the scan rate of $10 \mathrm{mV} / \mathrm{s}$ in an $\mathrm{O}_{2}$-saturated $\mathrm{KOH}$ solution $(0.1 \mathrm{~mol} / \mathrm{L})$.

\subsubsection{RRDE measurement}

The rotating speed of the working electrode was fixed at $1600 \mathrm{r} / \mathrm{min}$ with the scan rate of $10 \mathrm{mV} / \mathrm{s}$ in an $\mathrm{O}_{2}$-saturated $\mathrm{KOH}$ solution $(0.1 \mathrm{~mol} / \mathrm{L})$ for the RRDE test. The electron transfer number $(n)$ and the percentage of $\mathrm{HO}_{2}{ }^{-}$were calculated via the following equations [30,31].

$$
\begin{aligned}
n & =4 I_{\mathrm{d}} /\left(I_{\mathrm{d}}+I_{\mathrm{r}} / N\right) \\
\% \mathrm{HO}_{2}{ }^{-} & =200\left(I_{\mathrm{r}} / N\right) /\left(I_{\mathrm{d}}+I_{\mathrm{r}} / N\right)
\end{aligned}
$$

where $I_{\mathrm{d}}$ stands for the disk current, $I_{\mathrm{r}}$ represents the ring current, and $N$ is the current collection efficiency of the Pt ring, which is identified to be 0.43 in $\mathrm{K}_{3} \mathrm{Fe}[\mathrm{CN}]_{6}(2 \mathrm{mmol} / \mathrm{L})$ and $\mathrm{KCl}$ solution $(0.1 \mathrm{~mol} / \mathrm{L})$.

\section{Results and discussion}

\subsection{Reduction conditions optimization}


Firstly, the reduction conditions were optimized for the Pt containing precursor to achieve higher ORR activity. Specifically, the ramp rate and the reduction temperature were adjusted on $1.0 \mathrm{wt} \%$ Pt loaded D-AC precursor. This sample was reduced by a mixture gas of $5 \% \mathrm{H}_{2}-95 \%$ Ar at $400{ }^{\circ} \mathrm{C}$ for $5 \mathrm{~h}$ under different ramp rates. As can be seen from Fig. 1(a), all of the resulting $1.0 \mathrm{wt} \% \mathrm{Pt}$ loaded samples reduced with the ramp rate 1,5 and $10{ }^{\circ} \mathrm{C} / \mathrm{min}$ show improved ORR performance, especially their current densities are increased obviously as compared to their support D-AC. It means that the introduction of only $1.0 \mathrm{wt} \%$ Pt could effectively enhance the ORR activity of the obtained samples. Besides, it is shown that the sample D-AC@1.0\%Pt-5 (reduced with the ramp rate of $5{ }^{\circ} \mathrm{C} / \mathrm{min}$ ) exhibits more positive onset potential and higher current density than those of the sample D-AC@1.0\%Pt-1 (reduced with ramp rate of $1{ }^{\circ} \mathrm{C} / \mathrm{min}$ ) and D-AC@1.0\%Pt-10 (reduced with ramp rate of $10{ }^{\circ} \mathrm{C} / \mathrm{min}$ ), indicating that $5{ }^{\circ} \mathrm{C} / \mathrm{min}$ is a suitable ramp rate to reduce the Pt loaded $\mathrm{D}-\mathrm{AC}$ precursor. Therefore, the reduction ramp rate was fixed at $5{ }^{\circ} \mathrm{C} / \mathrm{min}$ for the following studies.

Apart from the ramp rate, the reduction temperature was probed as well. Previous investigations revealed that chloroplatinic acid $\left(\mathrm{H}_{2} \mathrm{PtCl}_{6}\right)$ can be reduced to metallic $\mathrm{Pt}$ in the presence of hydrogen at around $100{ }^{\circ} \mathrm{C}$ [32], and the reduction temperature has obvious influence on the particle size of Pt on the support [33]. In this study, the $1.0 \mathrm{wt} \%$ Pt loaded D-AC precursor was reduced at 200 to $500{ }^{\circ} \mathrm{C}$ for $5 \mathrm{~h}$ with the ramp rate of $5{ }^{\circ} \mathrm{C} / \mathrm{min}$ under a $5 \% \mathrm{H}_{2}-95 \% \mathrm{Ar}$ atmosphere. The LSV curves of the obtained samples in Fig. 1(b) show that the ORR activity of the $1.0 \mathrm{wt} \% \mathrm{Pt}$ loaded samples was firstly increased with the increase of the reduction temperature from 200 to 400 ${ }^{\circ} \mathrm{C}$, while decreased when the reduction temperature was further increased to $500{ }^{\circ} \mathrm{C}$, implying $400{ }^{\circ} \mathrm{C}$ is the optimal reduction temperature for the precursor.

Transmission electron microscopy (TEM) was applied to characterize the prepared samples under different reduction temperatures. From Fig. 2, it can be seen that Pt is uniformly dispersed on the D-AC support and the Pt particle sizes of the four samples reduced at 200 to $500{ }^{\circ} \mathrm{C}$ are mainly around $3 \mathrm{~nm}$. Besides, the size distributions are very narrow (Fig. 2, inserted histograms). Particularly, when the reduction temperature was increased from 200 to $400{ }^{\circ} \mathrm{C}$, the Pt particle sizes of the resulting samples are similar, still about $3 \mathrm{~nm}$ (Fig. 2(a) to (c)). However, when the reduction temperature was further raised to $500{ }^{\circ} \mathrm{C}$, the majority of the Pt particles are maintained at around $3 \mathrm{~nm}$, but it is easy to find some big Pt particles around $10 \mathrm{~nm}$ in the sample D-AC@1.0\%Pt-500 (Fig. 2(d)). It is shown that higher temperature reduction favors the aggregation of small Pt particles, which is in good agreement with the reported results [33]. Meanwhile, the enhanced crystallinity of the samples reduced with the elevating temperature from 200 to $400{ }^{\circ} \mathrm{C}$ may account for the ORR performance improvement $[34,35]$, since the Pt particle sizes are similar for the three samples (Fig. 2(a) to (c)). Combining the ORR performance with the TEM results for these samples, it is obvious that when the $\mathrm{Pt}$ mass loading is the same, both the size and crystallinity of the Pt particles may influence the ORR activity of the resultant catalysts.

\subsection{Material characterizations}

From the above discussions, it can be seen that the introduction of Pt into the defective carbon is an effective approach to increase its ORR activity. However, as it presents in Fig. 1(a), the ORR performance of the $1.0 \mathrm{wt} \% \mathrm{Pt}$ loaded D-AC sample synthesized under the optimized conditions is still less active than the commercial Pt/C (20 wt\% Pt). To further enhance the ORR activity of the D-AC, the Pt loading amount was increased to $5.0 \mathrm{wt} \%$ with the same preparation method in fabricating the D-AC@1.0\%Pt-400.

It can be observed from Fig. 3 that the $1.0 \mathrm{wt} \%$ Pt loaded sample D-AC@1.0\%Pt and the D-AC almost show the same XRD pattern, indicating the introduction of $1.0 \mathrm{wt} \% \mathrm{Pt}$ did not change the structures of the D-AC. Besides, no noticeable peaks for Pt were found in the XRD pattern of the D-AC@1.0\%Pt because of the low loading amount. However, when the Pt content was increased to $5.0 \mathrm{wt} \%$, distinct Pt peaks can be observed from the corresponding XRD pattern in Fig. 3. The three strong peaks prove the presence of the typical face-centered cubic structure of $\mathrm{Pt}$, which matches well with its standard XRD pattern (JCPDS Card No. 87-0640). Moreover, X-ray photoelectron spectroscopy (XPS) was utilized to detect the surface composi-
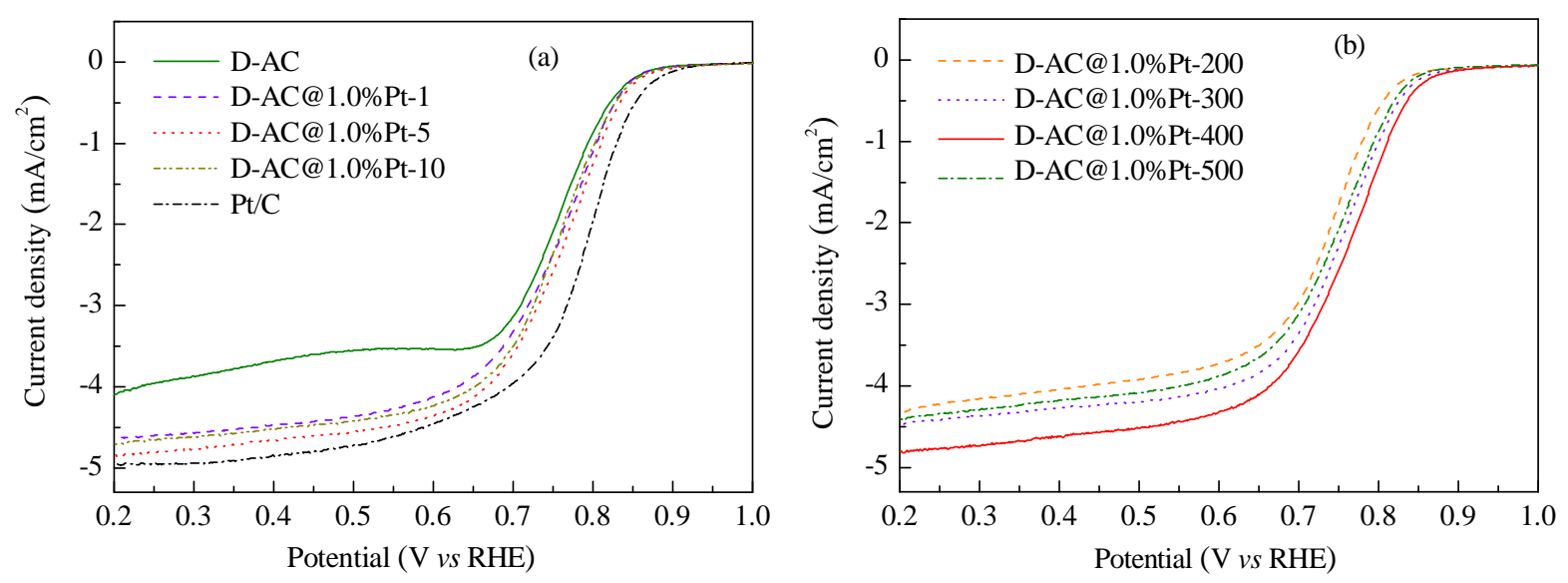

Fig. 1. The influence of (a) reduction ramp rate, and (b) reduction temperature on the ORR performance of the obtained samples. 

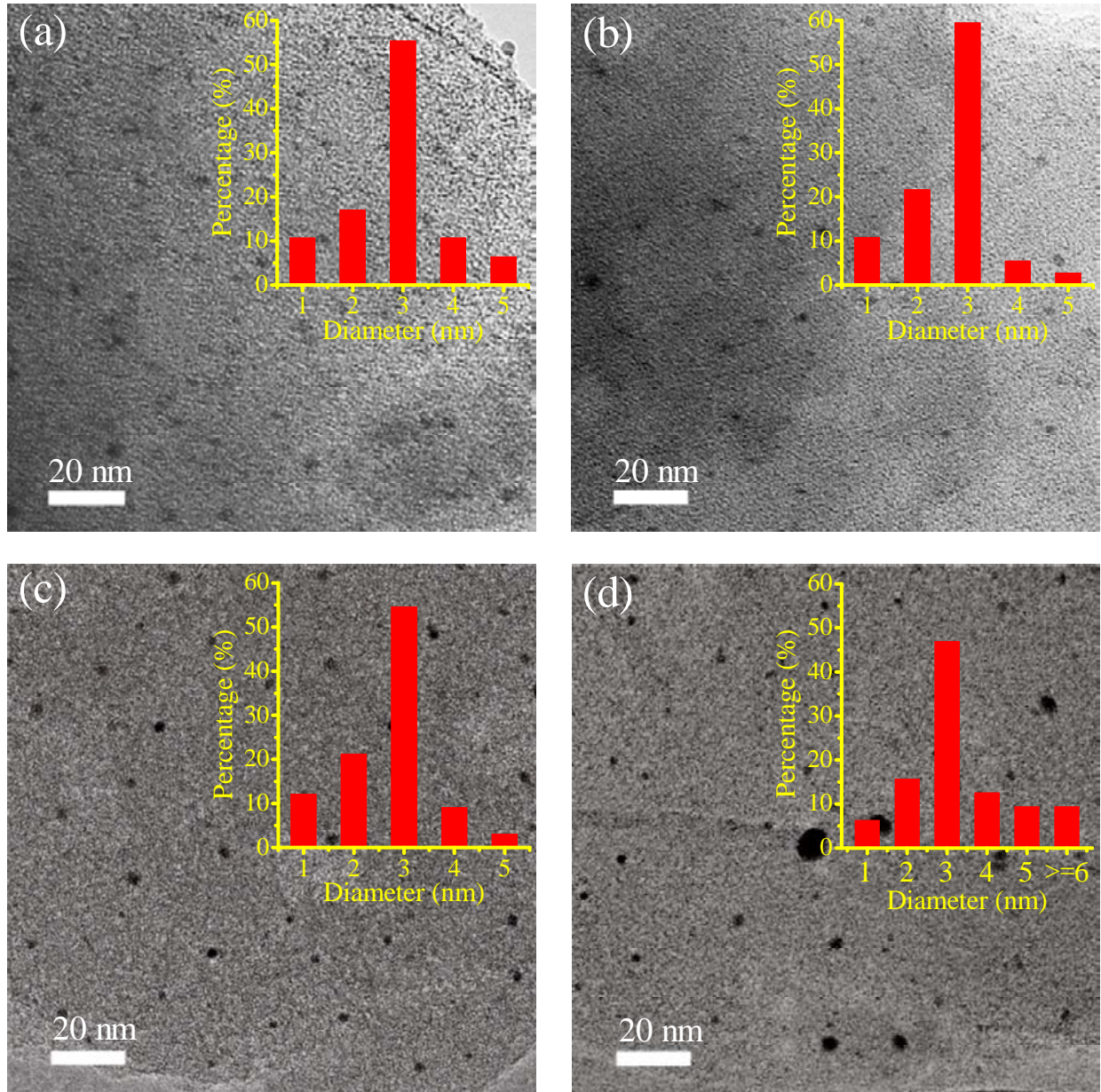

Fig. 2. TEM images of the prepared samples under different reduction temperatures. (a) D-AC@1.0\%Pt-200; (b) D-AC@1.0\%Pt-300; (c) D-AC@1.0\%Pt-400; (d) D-AC@1.0\%Pt-500. The insert histograms show the particle size distributions of Pt for the corresponding samples.

tion of the prepared samples. The XPS survey scan spectrum of the D-AC@1.0\%Pt in Fig. 4(a) shows that only C and 0 peaks can be observed, and no detectable peaks for the Pt can be found as its content is too low. Here, the Pt concentration of the D-AC@1.0\%Pt is measured to be 1.16 wt $\%$ by the ICP-MS test, which agrees well with the target value. Nevertheless, we can see weak Pt peaks from the XPS spectrum of the D-AC@5.0\%Pt

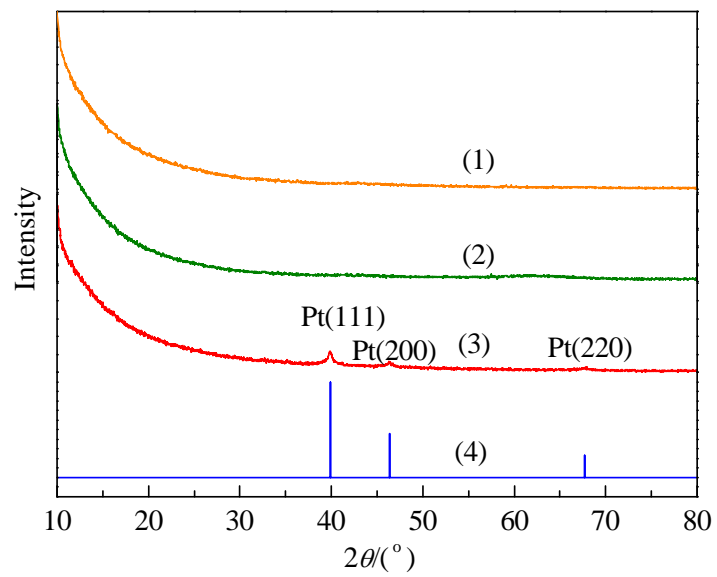

Fig. 3. XRD patterns of the synthesized samples. (1) D-AC; (2) D-AC@1.0\%Pt; (3) D-AC@5.0\%Pt; (4) Standard XRD pattern of Pt. in Fig. 4(a). The calculated Pt concentration from the XPS result in Fig. 4(a) for the D-AC@5.0\%Pt is 2.21 wt\%, which is lower than the designed amount of $5.0 \mathrm{wt} \%$. The possible reason is that the XPS is a kind of surface elemental analysis, which may not reflect the overall elemental information accurately. In this regard, ICP-MS was applied to further identify the Pt content in this sample. The ICP test result shows that the Pt content is $4.75 \mathrm{wt} \%$ in the D-AC@5.0\%Pt, which is very close to $5.0 \mathrm{wt} \%$. In addition, XPS high resolution scan was employed to gain more details regarding the configurations of $\mathrm{Pt}$ in the D-AC@5.0\%Pt. The deconvoluted two strong peaks at 71.2 and $74.5 \mathrm{eV}$ in the $\mathrm{Pt} 4 f$ region (Fig. $4(\mathrm{~b})$ ) are assigned to $\mathrm{Pt}^{0}$, while the broad peak at $75.2 \mathrm{eV}$ showing the existence of $\mathrm{Pt}^{2+}$ species [36-38]. It can be deduced that $\mathrm{Pt}^{0}$ is the predominant composition in the sample D-AC@5.0\%Pt, as illustrated by the relevant peak areas in Fig. 4(b).

Meanwhile, the D-AC@5.0\%Pt was further characterized by the TEM to probe the distribution and particle size of the loaded Pt. As shown in Fig. 4(c), Pt is homogeneously dispersed on the D-AC support. The majority of the Pt particles are around 5 $\mathrm{nm}$ in diameter, which is slightly bigger than that of the D-AC@1.0\%Pt samples (about $3 \mathrm{~nm}$ in Fig. 2), most likely due to that higher Pt loading amount is easy to facilitate the growth and aggregation of small Pt particles. The corresponding se- 

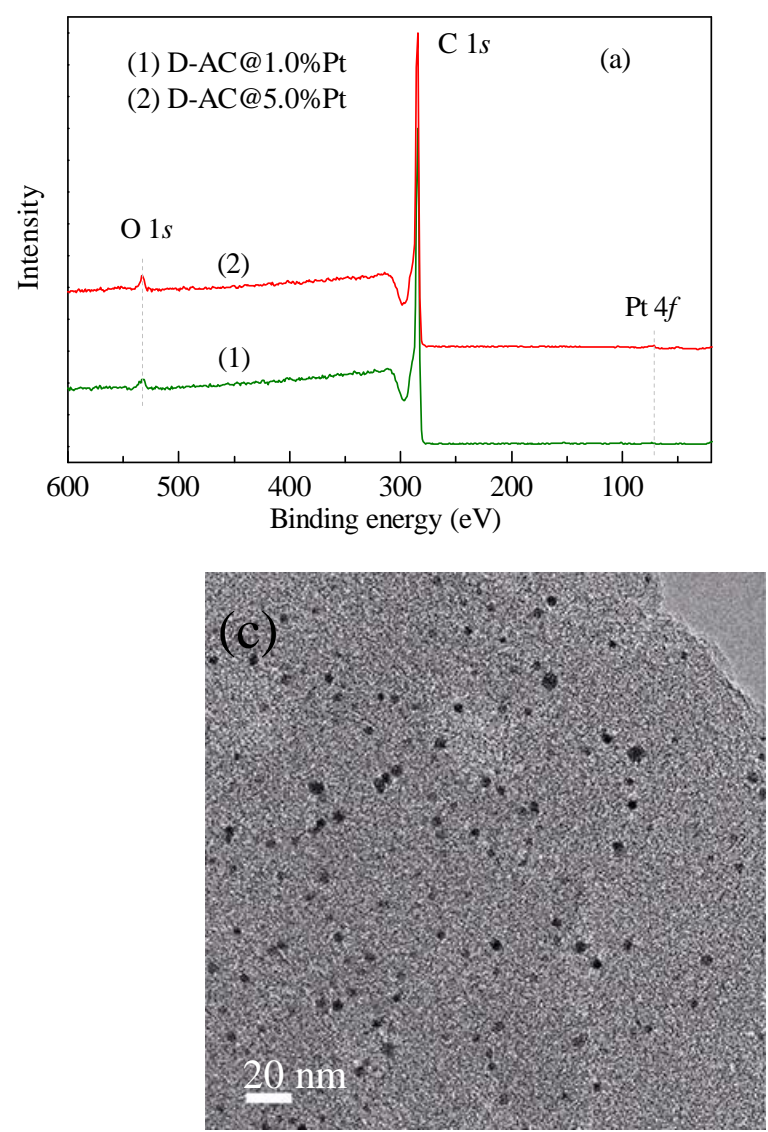
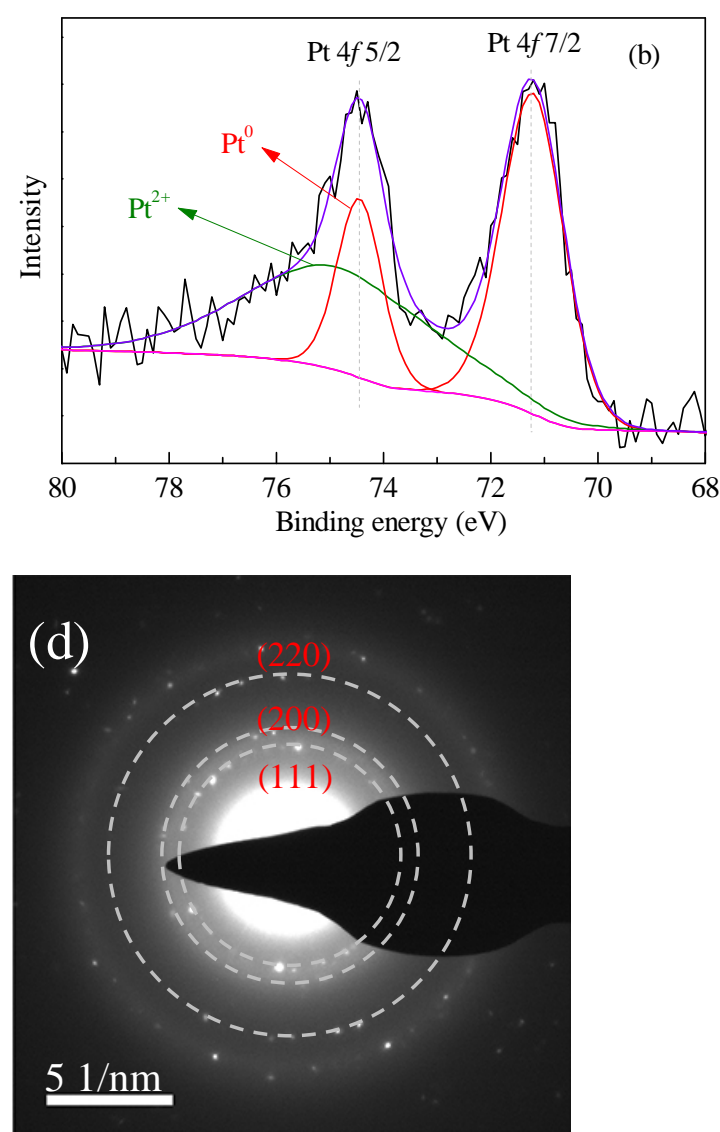

Fig. 4. (a) XPS survey scan spectra of the prepared samples D-AC@1.0\%Pt (1) and D-AC@5.0\%Pt (2); (b) High-resolution XPS spectrum of Pt 4f for sample D-AC@5.0\%Pt; (c) TEM image of the prepared sample D-AC@5.0\%Pt; (d) The corresponding SAED pattern.

lected area electron diffraction (SAED) pattern in Fig. 4(d) further confirms the cubic structure of the Pt in the D-AC@5.0\%Pt. For example, the calculated lattice spaces from the diffraction rings are $0.226,0.198$ and $0.135 \mathrm{~nm}$, respectively, which is consistent with the corresponding values of $\operatorname{Pt}(111), \operatorname{Pt}(200)$ and $\mathrm{Pt}(220)$ planes for the face-centered-cube crystal in Fig. 3.

\subsection{ORR Performance evaluations in an alkaline solution}

$\mathrm{CV}$ and RDE measurements were conducted in an $\mathrm{O}_{2}$-saturated $\mathrm{KOH}$ medium $(0.1 \mathrm{~mol} / \mathrm{L})$ to assess the ORR activity of the D-AC@5.0\%Pt, and the commercial 20 wt\% Pt/C was tested as a reference. It can be seen from Fig. 5(a) that the D-AC@5.0\%Pt exhibits a distinct cathodic ORR peak at $0.786 \mathrm{~V}$ (vs RHE), which is more positive than that of the commercial 20 wt $\%$ Pt/C (0.776 V, vs RHE), indicating the $5.0 \mathrm{wt} \% \mathrm{Pt}$ loaded $\mathrm{D}$-AC sample has outperformed the $\mathrm{Pt} / \mathrm{C}$ for the ORR. In addition, the remarkable ORR activity of the D-AC@5.0\%Pt can also be gleaned from the LSV test results in Fig. 5(b). For example, both the onset potential ( $\left.E_{\text {onset }}\right)$ and half-wave potential $\left(E_{1 / 2}\right)$ of the D-AC@5.0\%Pt are around $20 \mathrm{mV}$ more positive than those of the commercial Pt $/ \mathrm{C}\left(E_{\text {onset }}=0.922 \mathrm{~V}\right.$ vs $0.901 \mathrm{~V}, E_{1 / 2}=$ $0.805 \mathrm{~V}$ vs $0.785 \mathrm{~V}$ ). These results further prove that the synergistic effect between the defective carbon and the introduced Pt is very effective to promote the ORR, which meets our initial target that reducing the Pt content but without compromising the ORR activity of the obtained catalysts.

More detailed electrochemical investigations were carried out on the D-AC@5.0\%Pt to probe its electrocatalytic reaction mechanism. Firstly, the ORR kinetics was studied by the LSV on a RDE in an $\mathrm{O}_{2}$-saturated $\mathrm{KOH}$ solution $(0.1 \mathrm{~mol} / \mathrm{L})$ at different rotating speeds. From Fig. 6(a), it can be seen clearly that the current density shows a linear relationship with the rotation speed, signifying that the ORR is a well-defined kinetics controlled reaction. Moreover, the corresponding Koutecky-Levich (K-L) plots of the D-AC@5.0\%Pt under different potentials in Fig. 6(b) exhibits good linearity and parallelism, which further confirms the first-order reaction kinetics toward the dissolve of oxygen [39-41]. Besides, the outstanding ORR activity of the D-AC@5.0\%Pt is also reflected by the small Tafel slope of 63 $\mathrm{mV} /$ decade at low overpotentials, which is in the same level as the commercial Pt/C (48 mV/decade, Fig. 6(c)), indicating the protonation of the adsorbed oxygen ions on the active sites of the D-AC@5.0\%Pt is the rate determining step [42-44]. Meanwhile, the RRDE measurements were performed to reveal the reaction pathways of the D-AC@5.0\%Pt. As shown in Fig. $6(\mathrm{~d})$, the measured peroxide species yield is less than $4 \%$ over the potential range of 0.20 to $0.70 \mathrm{~V}$ ( $v s$ RHE) for the D-AC@5.0\%Pt, which is as low as that of the commercial Pt/C. The calculated electron transfer number $n$ is around 3.85, which is consistent with the value derived from the K-L plots (near 4.0, Fig. 6(b)), implying that the D-AC@5.0\%Pt could 

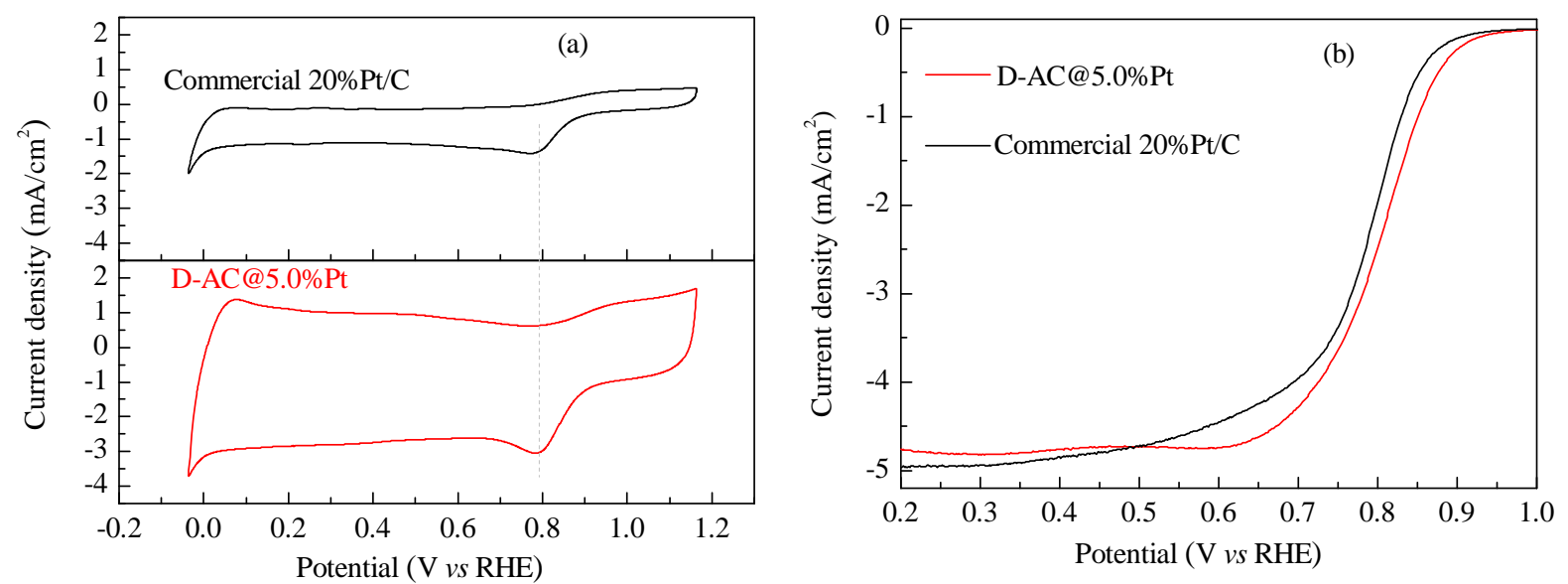

Fig. 5. (a) CV curves of the D-AC@5.0\%Pt and the commercial $20 \mathrm{wt} \% \mathrm{Pt} / \mathrm{C}$ tested in an $\mathrm{O}_{2}$-saturated $\mathrm{KOH}$ solution (0.1 mol/L); (b) LSV curves of the D-AC@5.0\%Pt and the commercial $20 \mathrm{wt} \% \mathrm{Pt} / \mathrm{C}$ measured at the scan rate of $10 \mathrm{mV} / \mathrm{s}$ with the rotation speed of $1600 \mathrm{r} / \mathrm{min}$ in an $\mathrm{O}_{2}$-saturated $\mathrm{KOH}$ solution $(0.1 \mathrm{~mol} / \mathrm{L})$.
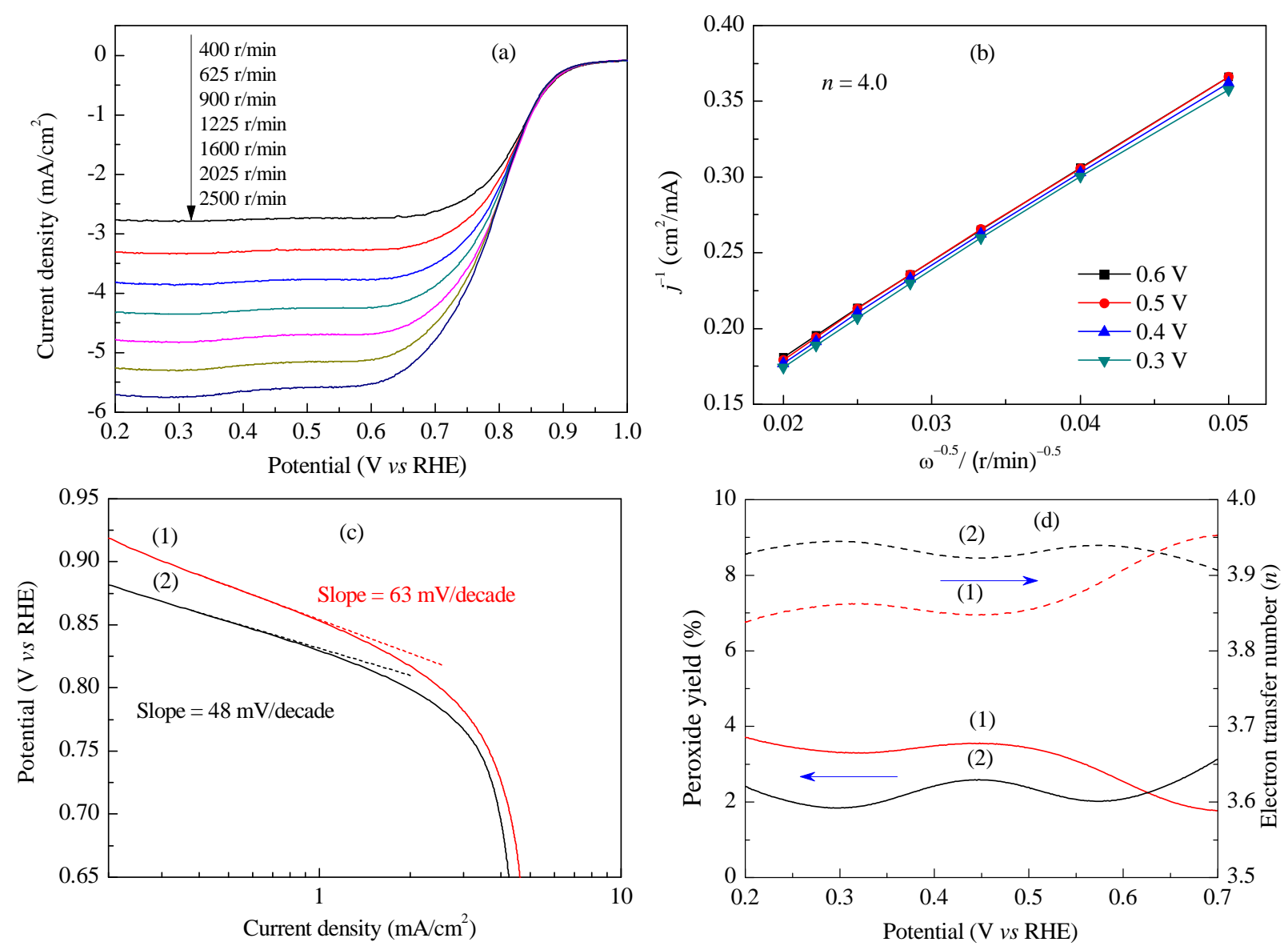

Fig. 6. (a) LSV curves at different rotation speeds with the scan rate of $10 \mathrm{mV} / \mathrm{s}$ in an $\mathrm{O}_{2}$-saturated $\mathrm{KOH}$ solution (0.1 mol/L) for the D-AC@5.0\%Pt; (b Koutecky-Levich (K-L) plots of the D-AC@5.0\%Pt at different potentials; (c) Tafel plots derived from the corresponding 1600 r/min LSV curves of the D-AC@5.0\%Pt (1) and Pt/C (2); (d) Percentage of peroxide species (solid lines) and the electron transfer number ( $n$ ) (dotted lines) of the D-AC@5.0\%Pt (1) and the commercial Pt/C (2) at different potentials (calculated from the corresponding RRDE data).

efficiently catalyze the ORR in the preferred one-step four-electron pathway in the alkaline medium.

Our previous investigations show that the defective carbon $\mathrm{D}$-AC derived from the low-cost activated carbon is much better than the Vulcan XC-72 carbon black for the ORR $[26,28]$. In this work, instead of using the traditional carbon black (e.g., Vulcan $\mathrm{XC}-72$ ) as a support for the Pt, the prepared D-AC sample was utilized for synthesizing a more efficient ORR catalyst. The resulting sample D-AC@5.0\%Pt only contains around 5.0 wt\% Pt (verified by the ICP test), but its ORR onset potential and 
half-wave potential have surpassed those of the commercial 20 wt\% Pt on the carbon black (Fig. 5(b)). It means that the selection of suitable support for the catalyst is crucial to the catalytic performance improvement, which agrees well with our earlier study [21]. As can be observed from Fig. 1(a), the pure D-AC is less active than the commercial $\mathrm{Pt} / \mathrm{C}$ for the ORR, while the introduction of $5.0 \mathrm{wt} \%$ Pt into the D-AC could make it outperform the Pt/C with $20 \mathrm{wt} \% \mathrm{Pt}$ (Fig. 5(b)). It is apparent that both the unique defects and the dispersed Pt particles on the D-AC played key roles in promoting the ORR. However, more in-depth and systematic investigations should be carried out to uncover the reaction mechanisms as well as the specific roles of the defects and Pt for the ORR, which will be helpful to design more efficient electrocatalysts for practical applications.

Besides the activity and cost issues, another deciding factor that restricts the commercialization of fuel cells is the unsatisfactory durability of the cathodic ORR catalysts. To this end, the stability of the resulting catalyst D-AC@5.0\%Pt was tested by the amperometric $i$ - $t$ method in an $\mathrm{O}_{2}$-saturated $\mathrm{KOH}$ solution ( $0.1 \mathrm{~mol} / \mathrm{L})$ with the rotating speed of $1000 \mathrm{r} / \mathrm{min}$, and the durability of the commercial $\mathrm{Pt} / \mathrm{C}$ was also measured under the same conditions as a comparison. From Fig. 7, it can be found that the D-AC@5.0\%Pt is more stable than the Pt/C in alkaline conditions. For example, the D-AC@5.0\%Pt only shows around $10 \%$ attenuation after continuous test for $20000 \mathrm{~s}$, while the $\mathrm{Pt} / \mathrm{C}$ exhibits much more severe decay (about $20 \%$ ) after the operation. The previous studies suggest that the main reason for the activity decline of Pt-based catalysts is that some Pt particles will experience dissolution and aggregation under the ORR conditions [45-47]. From Fig. 7, we can see that both the D-AC@5.0\%Pt and the Pt/C underwent evident current drop at the initial stage of the stability test, which should be ascribed to the removal of the unstable Pt from the carbon supports. However, the D-AC@5.0\%Pt is more stable than the Pt/C in the following stage, possibly due to the defects on the surface of the D-AC facilitated stronger interactions with Pt particles, thus slowed down the Pt dissolution. The superb activity and durability of the D-AC@5.0\%Pt render it favorable for alkaline fuel

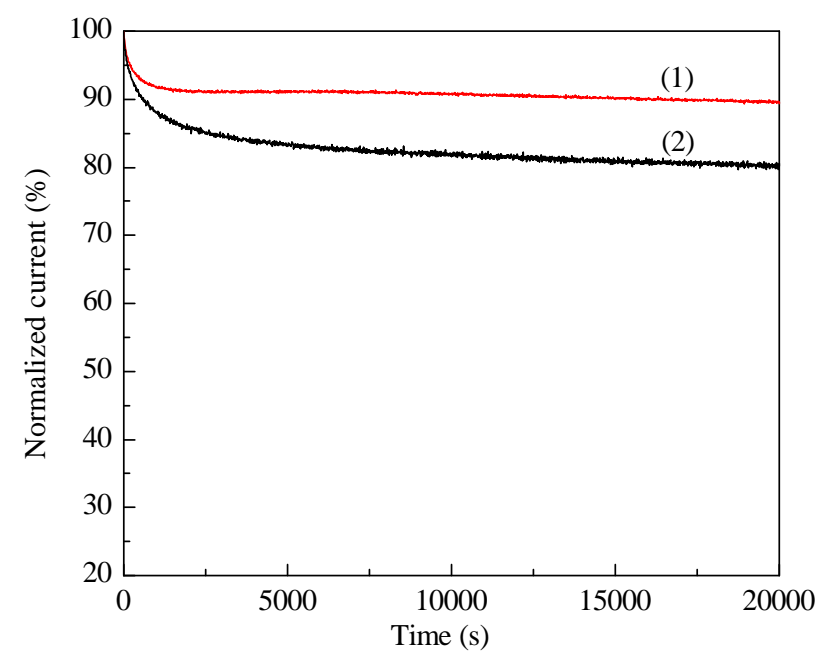

Fig. 7. Amperometric $i$ - $t$ stability test for the D-AC@5.0\%Pt (1) and the $\mathrm{Pt} / \mathrm{C}(2)$ with $1000 \mathrm{r} / \mathrm{min}$ in an $\mathrm{O}_{2}$-saturated $\mathrm{KOH}$ solution $(0.1 \mathrm{~mol} / \mathrm{L})$. cell applications.

\subsection{ORR performance evaluations in an acidic solution}

One disadvantage of alkaline fuel cells is that they require pure reaction gases (such as pure hydrogen and oxygen), since the carbon dioxide impurity will react with the alkaline electrolyte to form insoluble carbonates. The produced carbonates will obstruct the porous electrodes and the gas flow, resulting in cell performance failure [48]. It is therefore also highly desirable to develop active acidic ORR catalysts. Generally, most of the active metal-free or non-precious metal alkaline ORR catalysts could not efficiently catalyze the ORR in an acidic medium because they either lack active sites or the metal active sites are easy to dissolve in acidic conditions [49-51]. At present, Pt-based materials are still the most efficient acidic ORR catalysts $[4,12,15,52]$.

To evaluate the ORR performance of the resultant samples and the commercial $20 \mathrm{wt} \% \mathrm{Pt} / \mathrm{C}$ under acidic conditions, the prepared electrodes were tested in an $\mathrm{O}_{2}$-saturated $\mathrm{HClO}_{4}$ solution $(0.1 \mathrm{~mol} / \mathrm{L})$. The corresponding ORR polarization curves are shown in Fig. 8. As can be seen, the pure defective carbon D-AC displays very poor ORR activity in the $\mathrm{HClO}_{4}$ solution $(0.1$ $\mathrm{mol} / \mathrm{L}$ ), and even without steady current during the measured potential range. It is known that the reaction mechanisms of the ORR in alkaline and acidic media are different, and the corresponding active sites may not be the same. The unique defects in the D-AC sample are possibly not effective for the ORR in acidic conditions, so the activity is very low. However, the introduction of Pt could improve the ORR performance of the resulting samples obviously. From Fig. 8, we can notice that only introduce $1.0 \mathrm{wt} \% \mathrm{Pt}$ into the D-AC could enhance its ORR activity distinctly, and the performance is further improved when the Pt content is increased to $5.0 \mathrm{wt} \%$, in terms of the onset potential and current density. However, the D-AC@5.0\%Pt sample still shows inferior ORR activity than the commercial $20 \% \mathrm{Pt} / \mathrm{C}$ in acidic conditions (e.g., $E_{\text {onset }}=0.812 \mathrm{vs}$

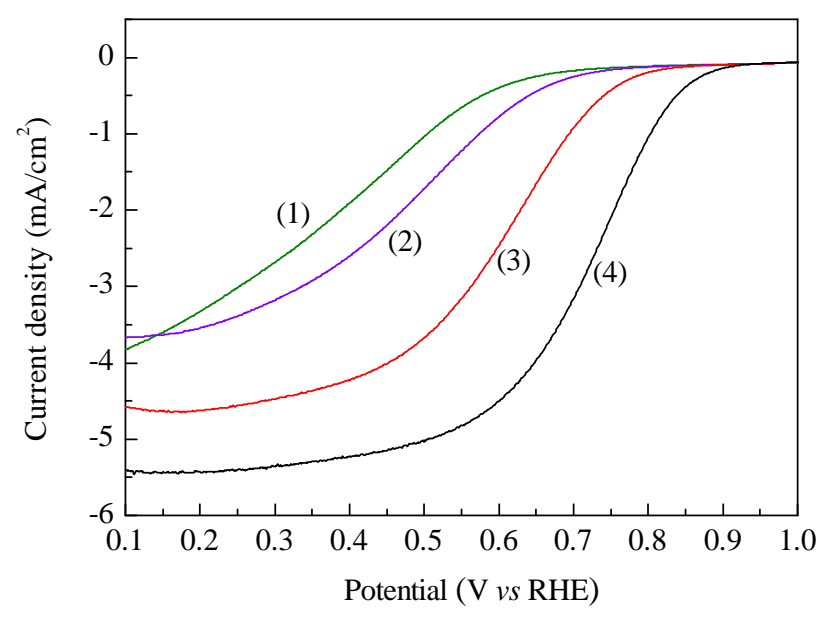

Fig. 8. Polarization curves of the samples D-AC (1), D-AC@1.0\%Pt (2), D-AC@5.0\%Pt (3) and the Pt/C (4) measured at the scan rate of 10 $\mathrm{mV} / \mathrm{s}$ with the rotation speed of $1600 \mathrm{r} / \mathrm{min}$ in an $\mathrm{O}_{2}$-saturated $\mathrm{HClO}_{4}$ solution $(0.1 \mathrm{~mol} / \mathrm{L})$. 
$0.892 \mathrm{~V} ; E_{1 / 2}=0.611$ vs $0.722 \mathrm{~V}$ (vs RHE)). Further improvement of the ORR activity in acidic solutions could be achieved by reducing the Pt particle size to sub-nanometers or atomic levels, which should be a desirable research topic in the future.

\section{Conclusions}

In the present study, a facile impregnation method was employed to synthesize defective carbon (D-AC) based ORR electrocatalysts with low Pt content, aiming to further improve the catalytic performance of the D-AC. The results show that the Pt particle size and crystallinity can be manipulated by tuning the thermolysis reduction process. Remarkably, the resulting sample D-AC@5.0\%Pt that only contains 5.0 wt\% Pt has outperformed the commercial $20 \mathrm{wt} \% \mathrm{Pt} / \mathrm{C}$ in terms of onset potential and half-wave potential in alkaline conditions, and it is more stable than the Pt/C. Besides, the D-AC@5.0\%Pt exhibits a one-step four-electron pathway for the ORR with extremely low yield of peroxide species. The excellent ORR activity of the D-AC@5.0\%Pt may attribute to both the unique defects in the $\mathrm{D}-\mathrm{AC}$ and the introduced Pt particles. It is revealed that the selection of suitable support for the electrocatalysts is of extreme importance. Meanwhile, the Pt loaded D-AC samples also show improved ORR performance in an acidic medium, although they are still less active as compared to the commercial $\mathrm{Pt} / \mathrm{C}$. Further research on downsizing the Pt particles is desirable to improve the ORR activity of Pt-based catalysts in acidic solutions.

\section{Acknowledgments}

This work was financially supported by the Australian Research Council (ARC).

\section{References}

[1] J. Snyder, T. Fujita, M. W. Chen, J. Erlebacher, Nat. Mater., 2010, 9, 904-907.

[2] B. C. H. Steele, A. Heinzel, Nature, 2001, 414, 345-352.

[3] V. R. Stamenkovic, B. Fowler, B. S. Mun, G. F. Wang, P. N. Ross, C. A. Lucas, N. M. Marković, Science, 2007, 315, 493-497.

[4] C. Chen, Y. J. Kang, Z. Y. Huo, Z. W. Zhu, W. Y. Huang, H. L. Xin, J. D. Snyder, D. G. Li, J. A. Herron, M. Mavrikakis, M. F. Chi, K. L. More, Y. D. Li, N. M. Markovic, G. A. Somorjai, P. D. Yang, V. R. Stamenkovic, Science, 2014, 343, 1339-1343.

[5] H. A. Gasteiger, S. S. Kocha, B. Sompalli, F. T. Wagner, Appl. Catal. B, 2005, 56, 9-35.

[6] A. Morozan, B. Jousselme, S. Palacin, Energy Environ. Sci., 2011, 4, 1238-1254.

[7] J. Kim, Y. Lee, S. H. Sun, J. Am. Chem. Soc., 2010, 132, 4996-4997.

[8] H. Yano, M. Kataoka, H. Yamashita, H. Uchida, M. Watanabe, Langmuir, 2007, 23, 6438-6445.

[9] C. Venkateswara Rao, B. Viswanathan, J. Phys. Chem. C, 2009, 113, 18907-18913.

[10] F. H. B. Lima, J. R. C. Salgado, E. R. Gonzalez, E. A. Ticianelli, J. Electrochem. Soc., 2007, 154, A369-A375.

[11] X. Q. Huang, Z. P. Zhao, L. Cao, Y. Chen, E. B. Zhu, Z. Y. Lin, M. F. Li, A. M. Yan, A. Zettl, Y. M. Wang, X. F. Duan, T. Mueller, Y. Huang, Science, 2015, 348, 1230-1234.

[12] S. J. Jiang, Y. W. Ma, G. Q. Jian, H. S. Tao, X. Z. Wang, Y. N. Fan, Y. N. Lu, Z. Hu, Y. Chen, Adv. Mater., 2009, 21, 4953-4956.

[13] M. V. Lebedeva, V. Pierron-Bohnes, C. Goyhenex, V. Papaefthimiou, S. Zafeiratos, R. R. Nazmutdinov, V. Da Costa, M. Acosta, L. Zosiak, R. Kozubski, D. Muller, E. R. Savinova, Electrochim. Acta, 2013, 108, 605-616.

[14] K. W. Nam, J. Song, K. H. Oh, M. J. Choo, H. Park, J. K. Park, J. W. Choi, Carbon, 2012, 50, 3739-3747.

[15] D. L. Wang, H. L. Xin, R. Hovden, H. S. Wang, Y. C. Yu, D. A. Muller, F. J. DiSalvo, H. D. Abruña, Nat. Mater., 2013, 12, 81-87.

[16] P. Mani, R. Srivastava, P. Strasser, J. Phys. Chem. C, 2008, 112,

\section{Graphical Abstract}

Chin. J. Catal., 2017, 38: 1011-1020 doi: 10.1016/S1872-2067(17)62765-7

Platinum stabilized by defective activated carbon with excellent oxygen reduction performance in alkaline media

Xuecheng Yan, Yi Jia*, Longzhou Zhang, Xiangdong Yao Griffith University, Australia
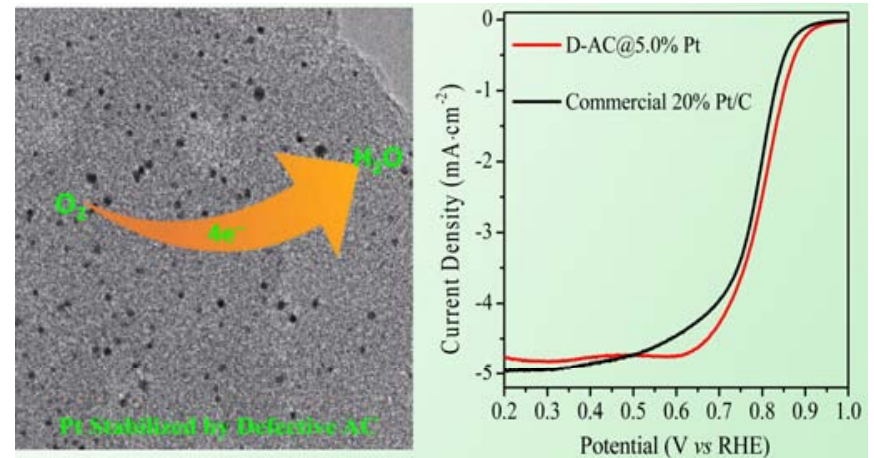

A highly efficient and durable oxygen reduction reaction electrocatalyst was prepared by stabilizing the nano-sized Pt particles with a kind of defective activated carbon. 
2770-2778.

[17] H. C. Tsai, Y. C. Hsieh, T. H. Yu, Y. J. Lee, Y. H. Wu, B. V. Merinov, P. W. Wu, S. Y. Chen, R. R. Adzic, W. A. Goddard III, ACS Catal., 2015, 5, 1568-1580.

[18] C. Koenigsmann, A. C. Santulli, K. P. Gong, M. B. Vukmirovic, W. P. Zhou, E. Sutter, S. S. Wong, R. R. Adzic, J. Am. Chem. Soc., 2011, 133, 9783-9795.

[19] H. Wang, H. H. Da, S. Ji, S. J. Liao, R. F. Wang, J. Electrochem. Soc., 2013, 160, H266-H270.

[20] S. Limpattayanate, M. Hunsom, J. Solid State Electrochem., 2013, 17, 1221-1231.

[21] X. C. Yan, Y. Jia, J. Chen, Z. H. Zhu, X. D. Yao, Adv. Mater., 2016, 28, 8771-8778.

[22] H. J. Liu, Y. L. Cao, F. Wang, Y. Q. Huang, ACS Appl. Mater. Interfaces, 2014, 6, 819-825.

[23] Z. X. Yan, M. M. Zhang, J. M. Xie, H. E. Wang, W. Wei, J. Power Sources, 2013, 243, 48-53.

[24] M. H. Seo, S. M. Choi, E. J. Lim, I. H. Kwon, J. K. Seo, S. H. Noh, W. B. Kim, B. Han, ChemSusChem, 2014, 7, 2609-2620.

[25] J. E. Park, Y. J. Jang, Y. J. Kim, M. S. Song, S. Yoon, D. H. Kim, S. J. Kim, Phys. Chem. Chem. Phys., 2014, 16, 103-109.

[26] X. C. Yan, Y. Jia, T. Odedairo, X. J. Zhao, Z. Jin, Z. H. Zhu, X. D. Yao, Chem. Commun., 2016, 52, 8156-8159.

[27] H. Y. Zhao, C. H. Sun, Z. Jin, D. W. Wang, X. C. Yan, Z. G. Chen, G. S. Zhu, X. D. Yao, J. Mater. Chem. A, 2015, 3, 11736-11739.

[28] X. J. Zhao, X. Q. Zou, X. C. Yan, C. L. Brown, Z. G. Chen, G. S. Zhu, X. D. Yao, Inorg. Chem. Front., 2016, 3, 417-421.

[29] Y. Jia, L. Z. Zhang, A. J. Du, G. P. Gao, J. Chen, X. C. Yan, C. L. Brown, X. D. Yao, Adv. Mater., 2016, 28, 9532-9538.

[30] U. A. Paulus, T. J. Schmidt, H. A. Gasteiger, R. J. Behm, J. Electroanal. Chem., 2001, 495, 134-145.

[31] Y. Y. Liang, Y. G. Li, H. L. Wang, J. G. Zhou, J. Wang, T. Regier, H. J. Dai, Nat. Mater., 2011, 10, 780-786.

[32] D. Radivojević, K. Seshan, L. Lefferts, Appl. Catal. A, 2006, 301, 51-58.

[33] S. Kaneko, M. Izuka, A. Takahashi, M. Ohshima, H. Kurokawa, H.
Miura, Appl. Catal. A, 2012, 427-428, 85-91.

[34] F. Fina, H. Menard, J. T. S. Irvine, Phys. Chem. Chem. Phys., 2015, 17, 13929-13936.

[35] M. R. Othman, N. N. N. Mustafa, A. L. Ahmad, Microporous Mesoporous Mater., 2006, 91, 268-275.

[36] J. N. Zheng, J. J. Lü, S. S. Li, M. W. Xue, A. J. Wang, J. J. Feng, J. Mater. Chem. A, 2014, 2, 3445-3451.

[37] J. F. Xu, X. Y. Liu, Y. Chen, Y. M. Zhou, T. H. Lu, Y. W. Tang, J. Mater. Chem., 2012, 22, 23659-23667.

[38] G. T. Fu, L. F. Ding, Y. Chen, J. Lin, Y. W. Tang, T. H. Lu, CrystEngComm, 2014, 16, 1606-1610.

[39] Z. Y. Liu, G. X. Zhang, Z. Y. Lu, X. Y. Jin, Z. Chang, X. M. Sun, Nano Res., 2013, 6, 293-301.

[40] X. Yang, L. F. Gan, C. Z. Zhu, B. H. Lou, L. Han, J. Wang, E. K. Wang, Chem. Commun., 2014, 50, 234-236.

[41] F. P. Pan, Q. P. Zhao, J. Wang, J. Y. Zhang, ChemElectroChem, 2015, 2, 2032-2040.

[42] M. De Koninck, B. Marsan, Electrochim. Acta, 2008, 53, 7012-7021.

[43] Y. Y. Liang, H. L. Wang, J. G. Zhou, Y. G. Li, J. Wang, T. Regier, H. J. Dai, J. Am. Chem. Soc., 2012, 134, 3517-3523.

[44] T. Odedairo, X. C. Yan, J. Ma, Y. L. Jiao, X. D. Yao, A. J. Du, Z. H. Zhu, ACS Appl. Mater. Interfaces, 2015, 7, 21373-21380.

[45] F. Hasche, M. Oezaslan, P. Strasser, Phys. Chem. Chem. Phys., 2010, 12, 15251-15258.

[46] H. Yano, T. Akiyama, P. Bele, H. Uchida, M. Watanabe, Phys. Chem. Chem. Phys., 2010, 12, 3806-3814.

[47] T. J. Kim, G. Kwon, Y. T. Kim, Chem. Commun., 2014, 50, 596-598.

[48] B. Y. S. Lin, D. W. Kirk, S. J. Thorpe, J. Power Sources, 2006, 161, 474-483.

[49] D. S. Su, G. Q. Sun, Angew. Chem. Int. Ed., 2011, 50, 11570-11572.

[50] C. H. Choi, M. W. Chung, H. C. Kwon, S. H. Park, S. I. Woo, J. Mater. Chem. A, 2013, 1, 3694-3699.

[51] K. Mamtani, U. S. Ozkan, Catal. Lett., 2015, 145, 436-450.

[52] J. B. Wu, H. Yang, Acc. Chem. Res., 2013, 46, 1848-1857.

\title{
负载铂的缺陷活性炭作为一种在碱性条件下具有优异氧还原反应性能的催化剂
}

\author{
严学成, 贾 毅, 张龙舟, 姚向东 \\ 澳大利亚格里菲斯大学自然科学学院和昆士兰微纳米技术中心，昆士兰 4111，澳大利亚
}

摘要: 燃料电池因其高的能量转化效率和无污染的特点而被认为是目前最有发展前景的高效清洁发电技术, 然而燃料电 池迟缓的阴极氧还原反应 $(\mathrm{ORR})$ 极大地降低了其整体性能. 目前, 铂碳 $(\mathrm{Pt} / \mathrm{C})$ 仍然是催化ORR最有效的催化剂. 但是, 由于 Pt 的价格很高以及其稳定性差等缺点极大地限制了燃料电池的大规模化应用, 因此设计与开发廉价高效稳定的ORR电催 化剂对实现燃料电池的大规模商业化应用具有重要的意义. 在过去的几十年中, 研究发现Pt和其他的非贵金属形成合金, 如Pt-Fe, Pt-Ni和Pt-Co等不仅可以降低Pt的用量, 而且也可以使所得催化剂具有较高的ORR活性. 此外, 研究发现核-壳结 构也可以提高铂基ORR催化剂的活性与稳定性. 但是, 这些催化剂的制备一般会使用毒性和危险性较高的有机化学试剂 并且其制备过程繁杂，因此并不适用于大规模的实际生产. 从这个角度来说，开发一种简易的方法来制备高效廉价的 ORR催化剂显得尤为重要.

之前的研究表明, Pt的载体对提高所得ORR催化剂来说非常关键. 可以发现大部分载体都是经过改进的碳材料, 如微 孔/介孔材料, 杂原子掺杂的石墨烯以及缺陷碳等. 尤其是我们课题组最近提出的一种缺陷催化机理表明, 在碳材料中特 定类型的缺陷(如缺陷活性炭(D-AC)和缺陷石墨烯等)可以使纯的碳材料具有很高的电催化活性. 尽管D-AC的ORR催化活 性在不含金属的催化剂中位居前列, 但是其催化性能仍然比商业化的 $\mathrm{Pt} / \mathrm{C}$ 差. 鉴于此, 如果我们可以通过使用具有较高 ORR催化活性的D-AC作为Pt的载体而降低Pt的用量, 但并不牺牲其催化活性, 这将是一个很具有前景的方法来解决昂贵 ORR催化剂的问题, 进而有可能实现燃料电池的大规模化生产. 
在本研究中, 我们通过一种简易的液相浸渍法以D-AC作为Pt的载体而制备了一种高效的ORR催化剂. 具体来说, 我 们通过调节合成过程中的还原温度实现了控制所得催化剂中Pt颗粒尺寸的目的，同时我们也对催化剂中的Pt含量对其催 化性能的影响进行了探讨. 研究表明, 所得催化剂中Pt的颗粒尺寸以及其结晶性都可能影响其ORR催化活性. 更为重要的 是, 所得样品D-AC@5.0\%Pt中含有约 $5 \mathrm{wt} \%$ 的Pt, 然而其在碱性条件下的ORR催化活性已经超过了商业化的含有 $20 \mathrm{wt} \%$ $\mathrm{Pt}$ 的Pt/C, 例如其起始电位和半波电位都优于商业化的Pt/C, 并且其稳定性也比商业化的Pt/C好. 除此之外, D-AC@5.0\% $\mathrm{Pt}$ 在催化 ORR 的过程中表现出了一种一步四电子的反应路径, 而且中间产物过氧化氢的产率很低. 所得催化剂 D-AC@5.0\%Pt优异的ORR反应活性表明D-AC中的特殊缺陷以及负载的Pt纳米颗粒都对提高其催化活性具有很大的贡献, 同时也说明选择合适的载体对提高电催化剂的活性至关重要. 实验结果还表明, D-AC@5.0\%Pt在酸性条件下的ORR催化 活性也有一定的提高, 虽然比商业化的Pt/C要差一些. 更进一步减小Pt的颗粒尺寸到亚纳米甚至原子级别可能会明显地提 高其在酸性电解液中的ORR催化活性.

关键词: 活性炭; 缺陷; 铂; 氧还原反应; 燃料电池

收稿日期: 2016-11-17. 接受日期: 2016-12-31. 出版日期: 2017-06-05.

*通讯联系人. 电话: +61-7-37355057; 传真: +61-7-37358021; 电子信箱: y.jia@griffith.edu.au 本文的英文电子版由Elsevier出版社在ScienceDirect上出版(http://www.sciencedirect.com/science/journal/18722067). 